\title{
Overview of atmospheric conditions during the Smoke, Clouds, and Radiation-Brazil (SCAR-B) field experiment
}

\author{
Carlos A. Nobre, Luiz F. Mattos, Claudine P. Dereczynski, Tatiana A. Tarasova, \\ and Igor V. Trosnikov \\ Centro de Previsāo de Tempo e Estudos Climáticos/Instituto Nacional de Pesquisas Espaciais, Cachoeira \\ Paulista, São Paulo, Brazil
}

\begin{abstract}
tbstract. The Smoke, Clouds, and Radiation-Brazil (SCAR-B) field experiment was conducted in central Brazil and southern Amazonia during the period August 15 to September 20, 1995. This paper presents an overview of atmospheric conditions during the SCAR-B period. A meteorological office was established in Brasília to support the mission flights and field activities. All the meteorological data collected during the SCAR3 have been archived and are available to the scientific community. The meteorological nditions throughout the SCAR-B period of August and September 1995 were near imatological conditions. Few synoptic-scale waves traveling from southeastern Pacific $\therefore$ ached Brazil, therefore the SCAR-B period was characterized by long periods of low umidity, dryness, little cloudiness, or rain, and haze events. The stable situation was terrupted due to the penetration of a frontal system on September 20, 1995, and a cond and more rain-producing one on September 28, 1995. Those two frontal systems in period of 10 days brought an end to the dry season. Air particle trajectories show that ist of the smoke below $4 \mathrm{~km}$ from Amazonia was transported to the south and then to 2 east exiting the continent at $25^{\circ} \mathrm{S}-30^{\circ} \mathrm{S}$. Radiative transfer calculations carried out for a clear sky gaseous and aerosol atmosphere show the decrease of the solar radiation iorption in the atmosphere-surface system due to smoke aerosol loading at the value m 5 to $50 \mathrm{~W} \mathrm{~m}^{-2}$ depending on the aerosol optical thickness, single-scattering albedo, it solar zenith angle.
\end{abstract}

\section{Introduction}

The Smoke, Clouds, and Radiation-Brazil (SCAR-B) field veriment, a joint research initiative of the National Aeroitics and Space Administration (NASA) and the Brazilian se Agency (AEB), which involved a number of Brazilian $\therefore$ U.S. institutions, took place over central Brazil and southAmazonia during the period August 15 to September 20, $\therefore$. An overview of SCAR-B is presented by Kaufman et al., - issue.

Veteorological support was provided during the field camIn. A meteorological support office was established in Bra1 at the Instituto Brasileiro do Mcio Ambiente e Recursos nováveis (IBAMA) and was staffed with meteorologists, gg data from the Centro de Previsão do Tempo e Estudos máticos (CPTEC), of the Instituto Nacional de Pesquisas aciais (INPE). One of the main goals of the office was to wide short- and medium-range weather forecasts to guide aircraft missions. Additionally, a database of meteorologmeasurements collected during the field experiment was pared to serve the SCAR-B scientific community in need of mospheric information to interpret their data.

This paper describes the atmospheric conditions during the AR-B field experiment. It reviews the prevailing long-term van atmospheric systems during the southern hemisphere $\checkmark \mathrm{H})$ winter over tropical South America and shows the main -zulation features of August and September 1995. It dis-

pyright 1998 by the American Geophysical Union.

ner number 98JD00992.

\$ $\$-0227 / 98 / 98 \mathrm{JD}-00992 \$ 09.00$ cusses the synoptic conditions at the end of September 1995 which, with the occurrence of the first seasonal rains in central and southeastern Brazil, determined the end of the mission. Lastly, it includes a calculation of air particle trajectories during the SCAR-B period and also a calculation of the radiative effect of smoke aerosols on the radiation balance of the atmosphere and at the surface.

\section{Data Sources}

Weather forecasts were elaborated using conventional observations, such as surface station and radiosounding airport data, from Instituto Nacional de Meteorologia (INMET) and Departamento de Eletrônica e Proteção ao Vôo (DEPV). In addition, the following data from Numerical Weather Prediction (NWP) models were used: CPTEC's global model and National Centers for Environmental Prediction (NCEP) operational models, The Medium-Range Forecast (MRF) and aviation (AVN). The AVN refers to the aviation model, which is identical to the MRF except that it runs from 1200 UTC data with an earlier data cutoff time and forecast only out to 72 hours. The satellite images used during the experiment are from various sources: National Oceanic and Atmospheric Administration (NOAA), Geostationary Operational Environmental Satellite (GOES), and METEOSAT. The University of Wisconsin provided GOES images at visible and infrared channels, with fire descriptions, smoke plumes, and $850 \mathrm{hPa}$ circulation trajectories. The SCAR-B meteorological data sets are available from CPTEC's public domain, as described in Figure 1 , organized in the following manner: CPTEC numerical weather forecast from 0000 and 1200 UTC are zonal and 


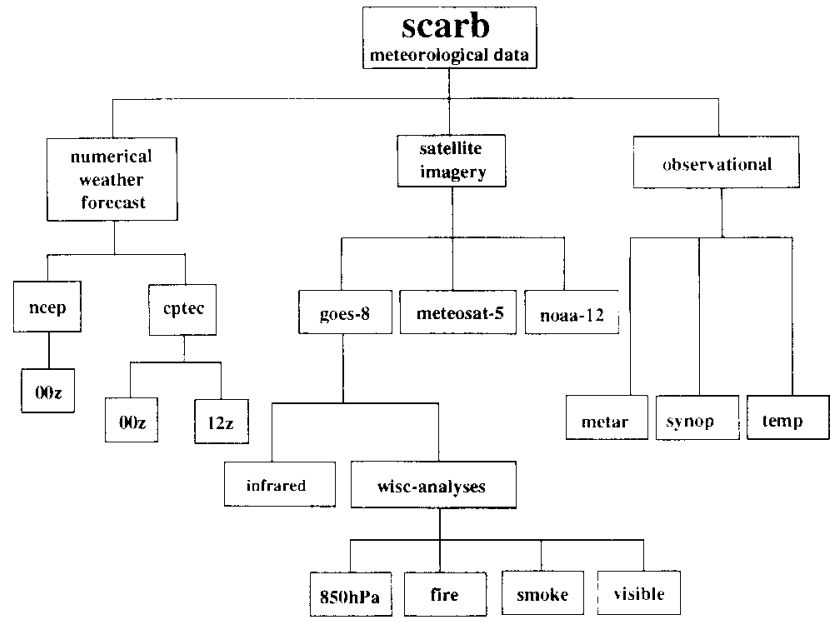

Figure 1. Box diagram of the SCAR-B directory organization, available at CPTEC public domain (yabae.cptec.inpe.br.).

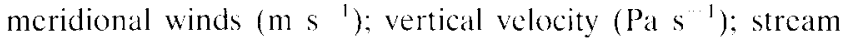
function $\left(\mathrm{m}^{2} \mathrm{~s}^{1}\right)$; velocity potential $\left(\mathrm{m}^{2} \mathrm{~s}^{1}\right)$; geopotential height $(\mathrm{m})$; absolute temperature $(\mathrm{K})$; relative and specific humiditics at $10000,850,700,500,300$, and $200 \mathrm{hPa}$; surface temperature (K); and sea level pressure (hPa). These 24-120 hour forecasts are available for the area $60^{\circ} \mathrm{S}$ to $15^{\circ} \mathrm{N}$ and $100^{\circ} \mathrm{W}$ to $10^{\circ} \mathrm{W}$, with a horizontal resolution of $1.875^{\circ} \times 1.875^{\circ}$ NCEP products from 0000 UTC are geopotential height $(\mathrm{m})$ at $1000,700,500$, and $300 \mathrm{hPa}$; relative humidity at 1000,850 and $700 \mathrm{hPa}$; zonal and meridional winds $\left(\mathrm{m} \mathrm{s}^{1}\right.$ ) at 850,500 , and $250 \mathrm{hPa}$; sea level pressure (hPa); absolute vorticity (s ') at $500 \mathrm{hPa}$; and absolute temperature $(\mathrm{K})$. These analyses and 24-120 hour forecasts are available for the area $90^{\circ} \mathrm{S}$ to equator and $120^{\circ} \mathrm{W}$ to $10^{\circ} \mathrm{W}$, with a horizontal resolution of $2.5^{\circ} \times$ $2.5^{\circ}$. From the GOES 8 satellite there are two types of products: daily infrared and analyzed images from University of Wisconsin: stream function at $850 \mathrm{hPa}$, fire pixels, smoke trajectory ficld, and visible channel showing the smoke/clouds mixing. In addition, infrared Meteosat 5 and visible NOAA 12 images are available. Conventional observational data are hourly airport (METAR) and meteorological surface station (SYNOP) reports and twice daily tropospheric sounding (TEMP), except for Alta Floresta $\left(9.52^{\circ} \mathrm{S}, 56.0^{\circ} \mathrm{W}\right)$, where there are soundings every 3 hours from August 17 to 30, 1995.

\section{Long-Term Mean Features of SH Winter Circulation and Precipitation over Tropical South America}

The main large-scale circulation features of $\mathrm{SH}$ winter over tropical South America are illustrated schematically in Plate 1: the quasi-stationary Intertropical Convergence Zone (ITCZ) over the tropical Atlantic and Pacific Oceans and associated convective activity in northwestern South America (Colombia, Venezuela) and Central America, the transient frontal systems (FSs) with their associated cold fronts at the surface in temperate and subtropical South America, and the South Atlantic Subtropical High (SASH) pressure system.

The variability of precipitation over central tropical South America is dominated by clear seasonal cycle with the rainy season during the SH spring and summer and the dry season during the winter and autumn. Most of central South America receives scanty rainfall during winter. During the dry season period of SCAR-B, precipitation maxima occur over Colombia, Venezuela, Central America, and over the ITCZ of both the tropical Pacific and the Atlantic Occans. The equatorial belt of low pressures associated with the ITCZ exhibits a seasonal cycle in the meridional displacement which lags 3-t months the maximum of solar heating. During August it reaches its northernmost position at about $10^{\circ} \mathrm{N}$, associated to maximum sea surface temperatures (SST). Precipitation falls off rapidly south of the equator in SH winter.

Winter marks the time of the year when the upper tropospheric subtropical jet is stronger and further equatorward over South America. Atmospheric heating over the ITCZ creates the descending branch in the subtropics at the latitude of the jet stream. During this season the subtropical anticyclonic high pressure in the South Atlantic is centered farther to the west, reaches its annual peak (around $1024 \mathrm{hPa}$ ), and exhibits a westward extension of high pressures toward the continent over Brazil. Episodes of extremely low values of relative humidity over central South America during winter (relative humidity values as low as $15 \%$ are observed) can only be explained by large-scale subsidence of upper tropospheric dry air |Figueroa and Nobre, 1990|. It is noteworthy that the dryness of the air over central Brazil and southern Amazon during this scason is an important factor in biomass burning.

The stable troposphere with light to moderate easterly winds and moderate temperatures, which dominates much of central South America during the SH winter, is related to the SASH circulation. The center of the SASH moves scasonally to the east over the Atlantic Ocean in the summer and to the west toward the continent in the winter, when the SASH ridge increases from the center to the border, with easterly winds on the eastern, central, and northern SCAR-B regions. West of the SCAR-B area, lowest-level winds are lighter, temperatures are higher, and pressures are lower.

The annual cycle of precipitation over southern Amazonia and central Brazil shows an interesting feature. According to Figueroa and Nobre [1990] by the end of August, convection starts to migrate in the Amazon Basin toward its western position over Brazil and Peru and keeps its southward migration to the end of September. By that time, moderate convection is also observed over southeastern Brazil. At the end of September the two systems merge and a well-defined band of convection-oriented NW-SE is established. During this transition, the typical circulation systems of the $\mathrm{SH}$ summer are also established: the subtropical jet is displaced to the south and the upper tropospheric Bolivian high is formed, as well as the so-called South Atlantic Convergence Zone (SACZ) and the low-level moisture-laden jet transporting moisture from Amazonia to subtropical South America, typically Paraguay and northern Argentina, favoring the establishment of convective complexes.

In general, the rainy season starts in August over the western portion of Brazil, in September from Mato Grosso to São Paulo and in October for areas farther to the northeast. The onset of the rainy season can last for a maximum period of a month, but the transition between winter dry conditions to summer wet conditions can be sometimes very swift, occurring in only 5 days [Kousky, 1988; Horel et al., 1989]. The date of the onset of the rainy season also shows large interannual variability [Sugahara, 1991; D'Almeida and Grimm, 1996]. The mechanisms which cause the large interannual variability of the 


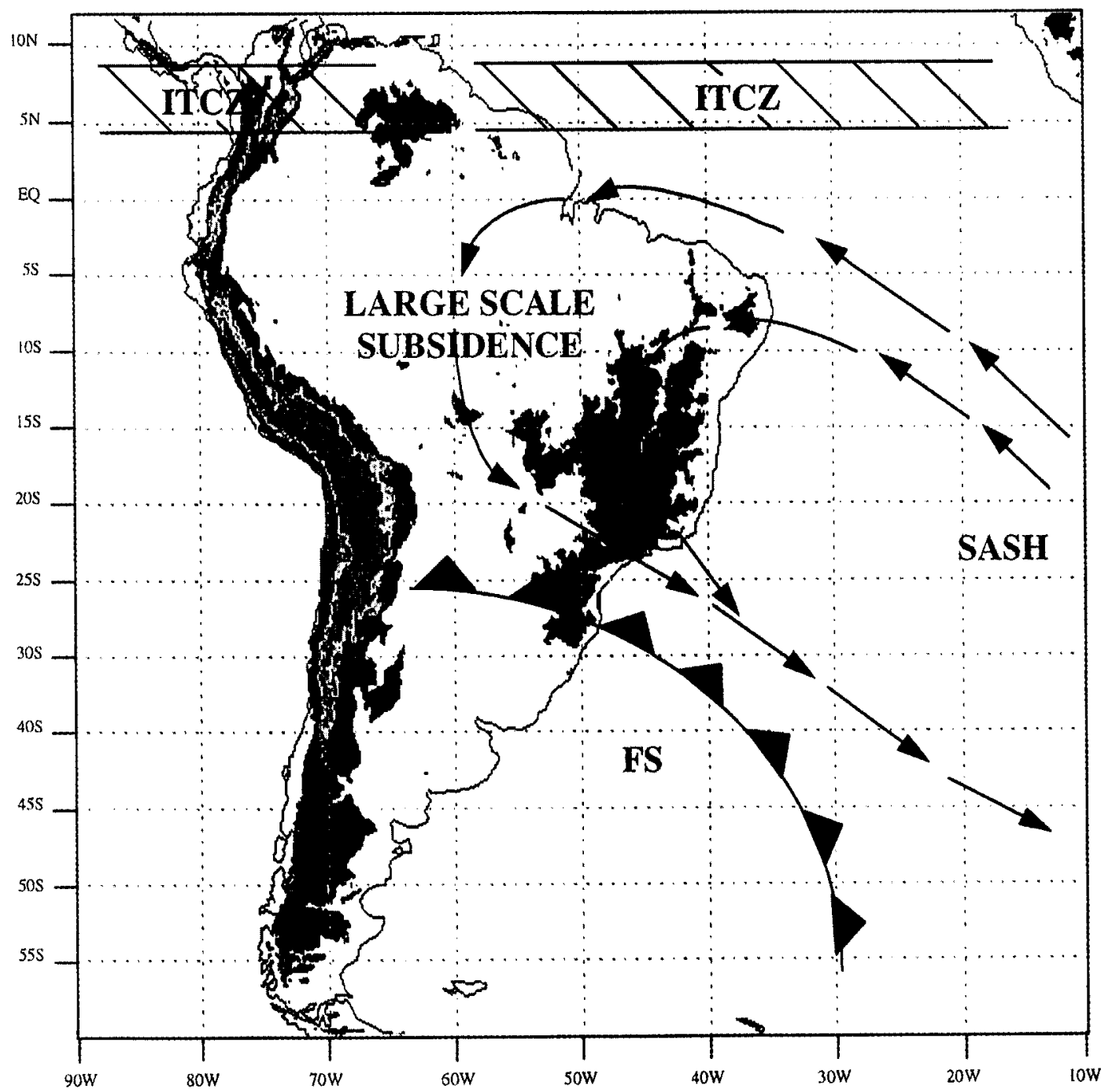

Plate 1. Main SH winter systems in SCAR-B area.

t of the rainy season and reasons for the abrupt transition $\therefore$ not yet been explained.

+ large portion of the intraseasonal variability of rainfall $\therefore$ Brazil throughout the year is associated to the penetration .) d fronts originating in midlatitudes. The trajectory of the :tal systems over South America follows two distinct sea. 1 patterns. Their summer propagation is slower and charrized by greater convective activity due to complex interans between the transient, synoptic-scale waves and the $\therefore$ i-stationary systems: Bolivian high and the SACZ $\because$ :eroa, 1997]. The winter frontal systems move faster and a more zonal trajectories farther to the south. These sys... do not induce appreciable convective activity over central $\therefore$ southeastern Brazil but, occasionally, cause strong equaward cold air advection, which further stabilizes the lower mosphere over central Brazil and southern Amazonia.

During winter the synoptic-scale waves follow a more zonal iectory primarily over the southeastern Pacific along the tudes of the subtropical $\left(30^{\circ} \mathrm{S}\right)$ and subpolar $\left(50^{\circ} \mathrm{S}\right)$ jets. ir penetrating over the extratropical South America they plify meridionally at the same time that they propagate to $\therefore$ northeast [Berbery and Vera, 1996]. Gan and Rao [1994] estigated the influence of the Andes on transient disturnces. Their analyses show that waves approaching the Andes turn anticyclonically at low levels and exhibit zonal trajectory at upper levels, which implies a decrease in the vertical tilt of the system on the windward side and an increase in the tilt on the lee side, resulting in increased baroclinicity on the lee side and lee cyclogenesis. The frontal systems associated to these waves propagate rapidly during the winter over regions of low humidity and longwave radiation losses mainly over central and central western Brazil. Sometimes in $\mathrm{SH}$ winter these waves bring cold air from higher latitudes into Amazonia, producing a sharp drop of surface temperatures known as "Friagens" [Parmenter, 1976; Marengo et al., 1997]. Another common feature of these SH winter waves is that they produce very little precipitation (convective or large-scale precipitation). Starting in the $\mathrm{SH}$ spring, the frontal systems continue to propagate over Brazil, but they move more slowly and they are very important in organizing regional convection [Kousky and Molion, 1981; Oliveira and Nobre, 1986; Figueroa, 1997]. The SACZ is a zone where frontal systems become climatologically quasi-stationary [Kodama, 1992; Kousky, 1979; Figueroa, 1997]. The penetration of these systems enhance the conditions which determine the positioning and intensity of the SACZ as the locus of convergence of cold air from the south and moistureladen air from Amazonia. 


\section{PRECIPITATION (mm)}

\section{Total}

(a) Aug

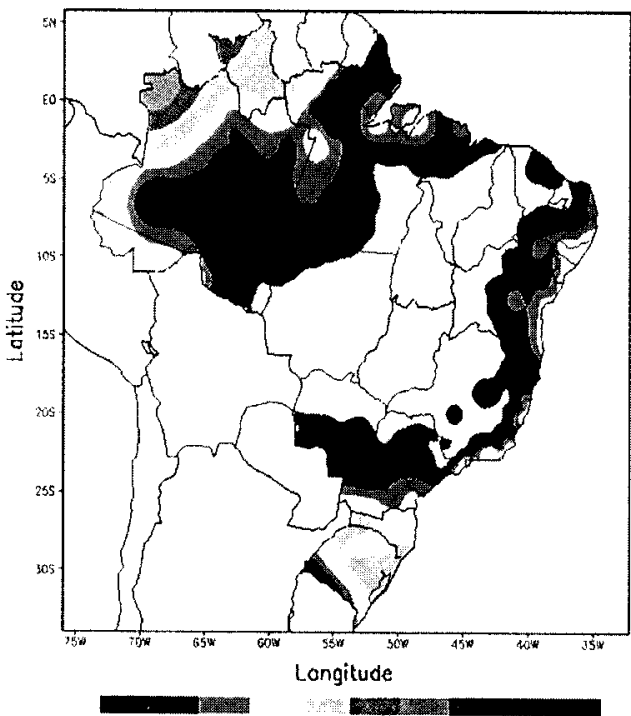

$\begin{array}{llllll}10 \quad 30 & 50 & 100 \quad 200 \quad 300 \quad 400 \quad 800 \quad 800\end{array}$

(c)

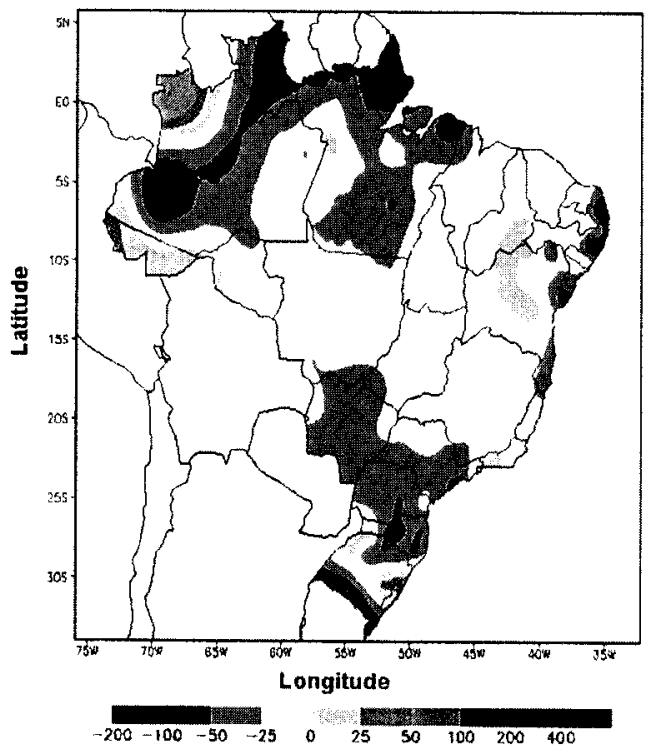

(b) $\operatorname{Sep}$

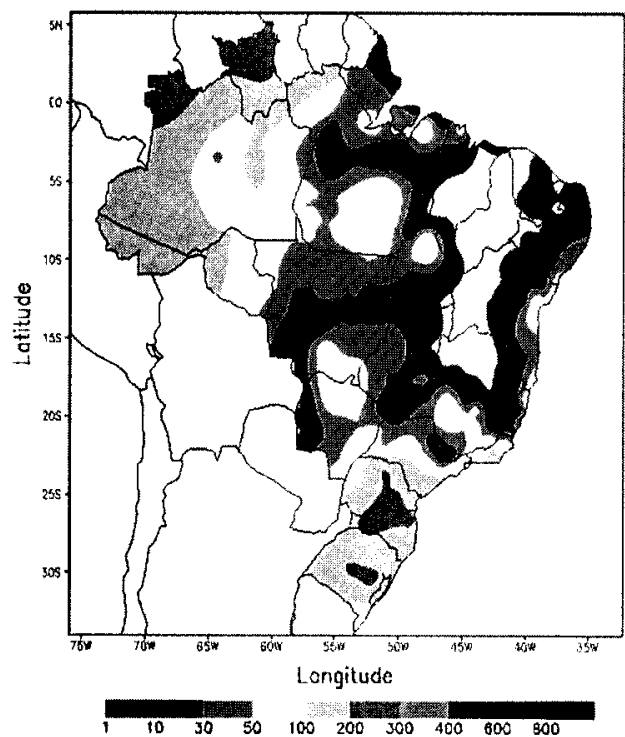

Anomalies

(d)

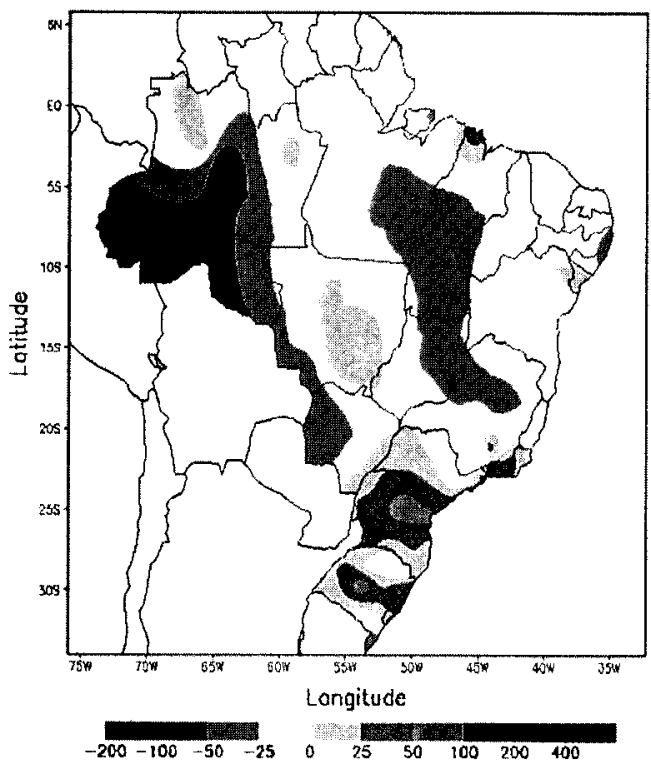

Plate 2. Total precipitation (mm) in 1995: (a) August, (b) September, (c) August anomalies, and (d) September anomalies.

\section{Atmospheric Conditions in August} and September 1995

\subsection{Mean Atmospheric Conditions}

The large-scale conditions in the Tropical Pacific Ocean during SCAR-B showed the existence of a moderate cold southern oscillation (SO) phase. In March-April 1995 the SST anomalies changed from positive to negative, breaking a long period of warm. El Niño-like conditions that started in 1991. It has to be remarked, however, that most of central and southeastern Brazil are not affected significantly by either phase of 


\title{
TEMPERATURE $\left({ }^{0} \mathrm{C}\right)$
}

\author{
Mean fields
}

(a) Aug

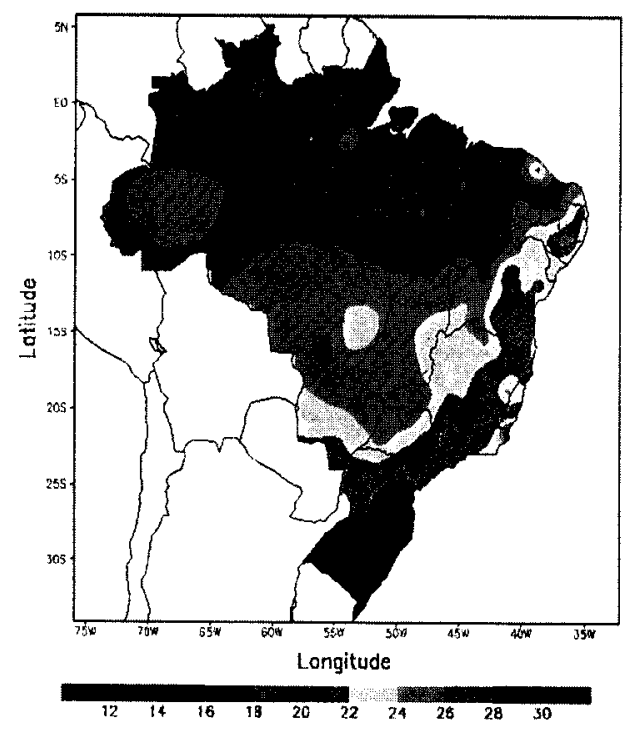

(c)

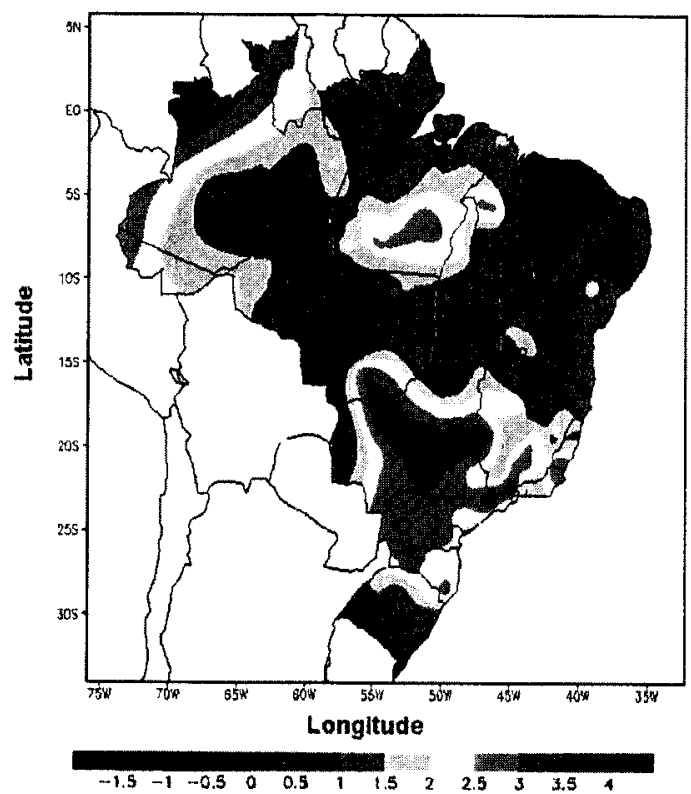

(b) Sep

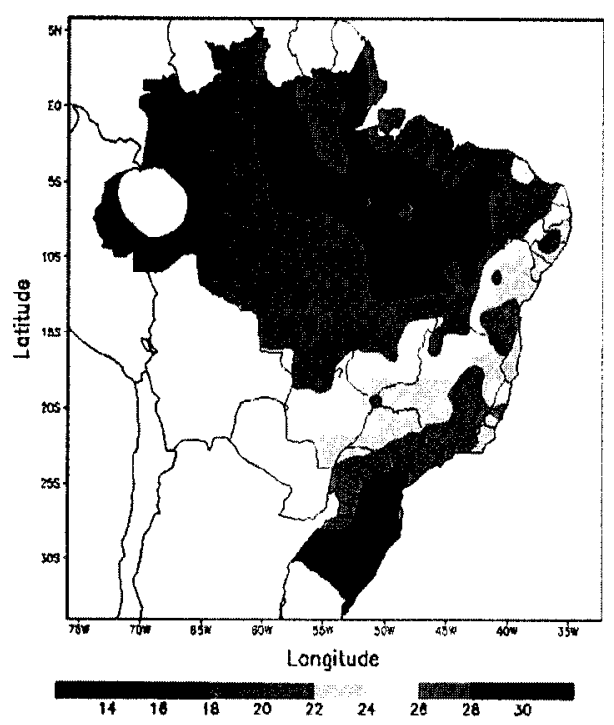

Anomalies

(d)

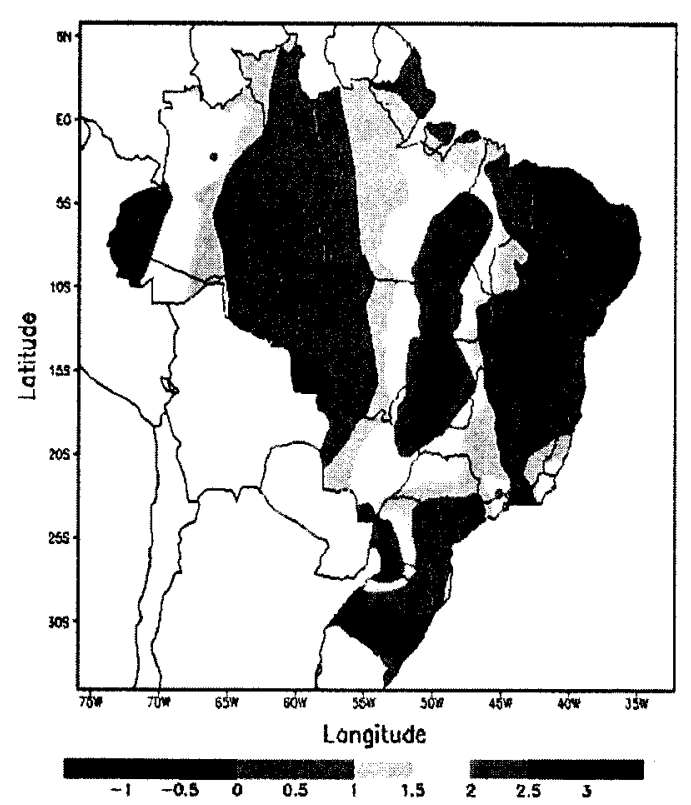

Plate 3. Mean temperaturc $\left({ }^{\circ} \mathrm{C}\right.$ ) in 1995: (a) August, (b) September, (c) August anomalies, and (d) September anomalies. 

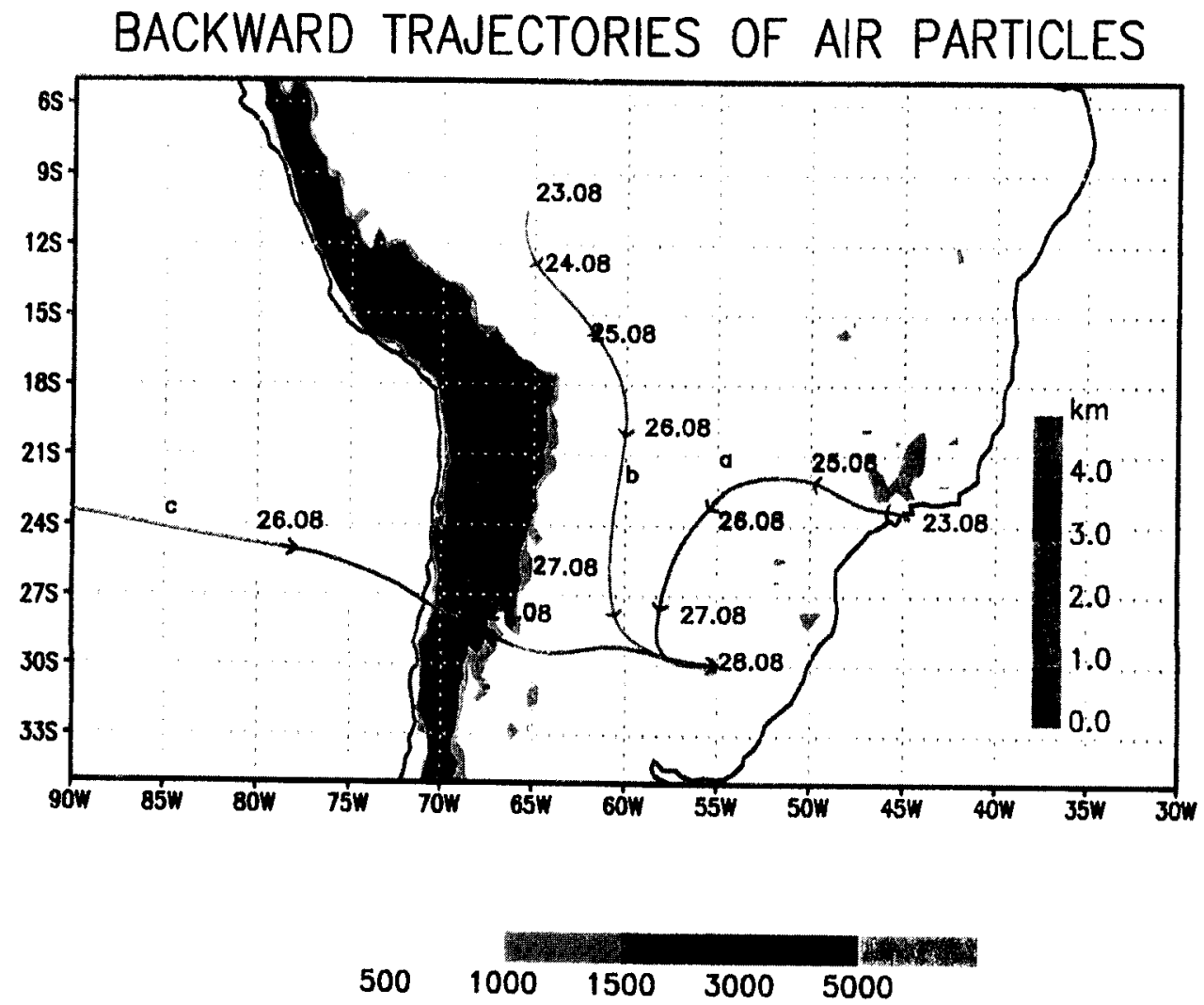

Plate 4. Backward trajectories of air particles on the isentropic surfaces (a) $305 \mathrm{~K}$, (b) $308 \mathrm{~K}$, and (c) 315 $\mathrm{K}$ for period from August 23, 1995, to August 28, 1995. The vertical bar shows trajectory altitude in kilometers. The horizontal bar indicates topography height in meters.

the SO, except by colder (warmer) winter temperatures in the strong cold (warm) SO phase [CPTEC/INPE, 1996].

FS blocking at hemispheric scale was observed since July 1995 as identified by persistent positive geopotential height anomalies at $500 \mathrm{hPa}$ in the South Pacific Ocean [CPTECINPE, 1995a]. This blocking lasted through August and has led to drought conditions in Argentina, as pointed out by Nuñez et al. [1996] and Allessandro and Liechtenstein, [1996], and in southern Brazil in August [Nascimento and Ambrizzi, 1996]. During the first 30 days of the experiment, when the lower troposphere anticyclone was dominant over the SCAR-B area, few cold fronts reached Brazil. The FS that managed to move farther equatorward soon were diverted to the South Atlantic Ocean, with its transient anticyclones merging with the SASH,

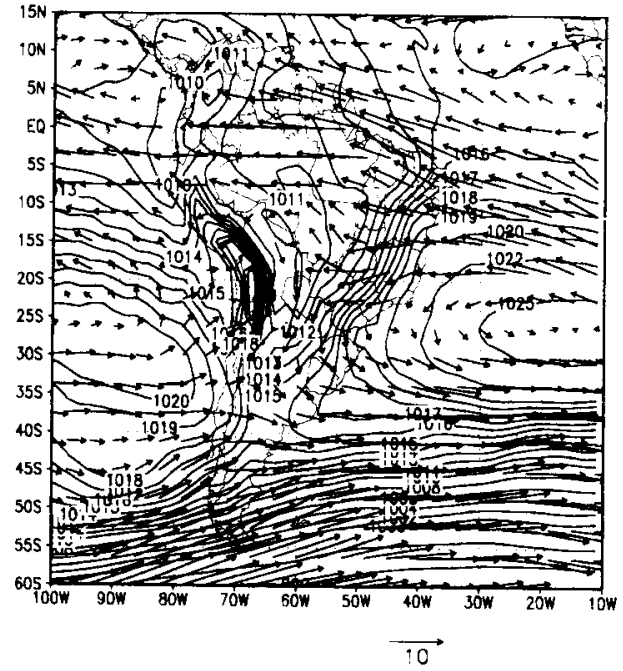

(d)

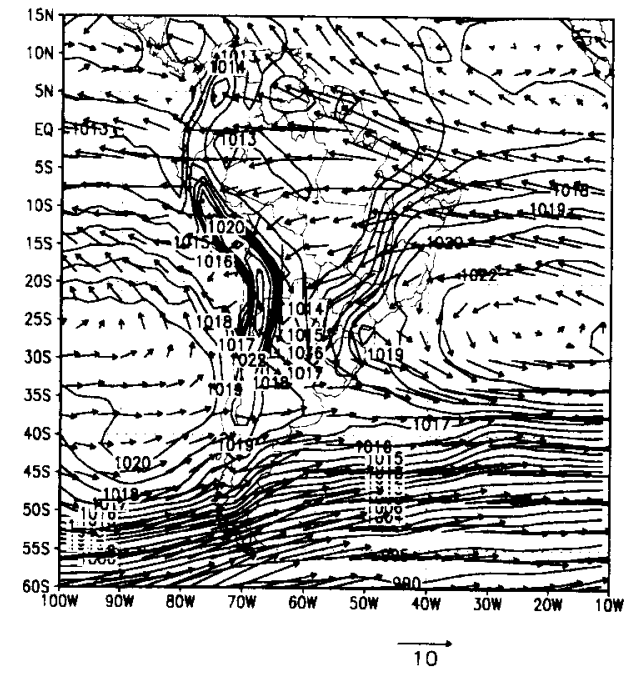

(b)

Figure 2. Averaged sea level pressure (hPa) and $850 \mathrm{hPa}$ wind $\left(\mathrm{m} \mathrm{s}^{-1}\right)$ during SCAR-B period: (a) 0000 and (b) 1200 UTC. 


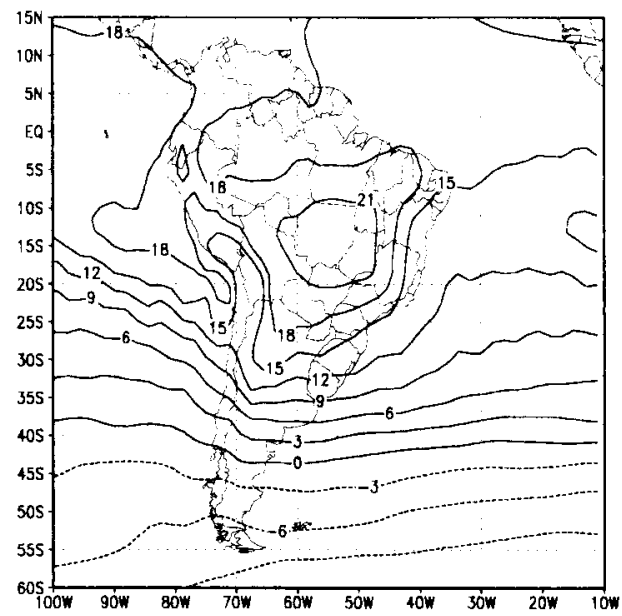

(a)

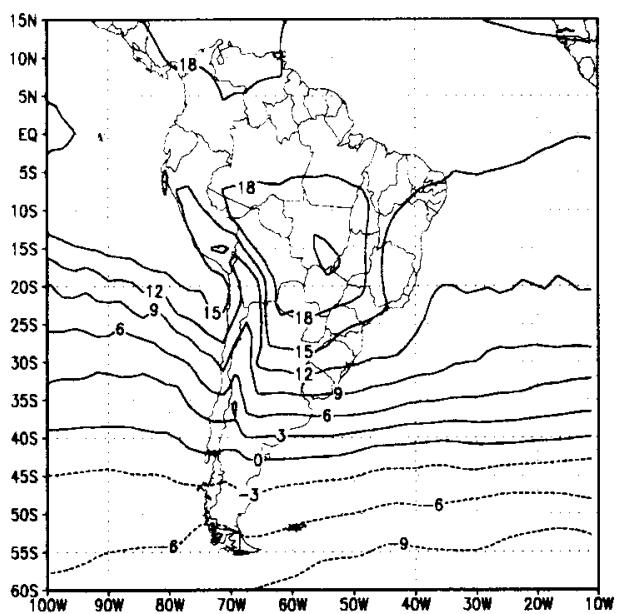

(b)

Figure 3. Averaged 850 hPa temperature ("C) during SCAR-B period: (a) 0000 and (b) 1200 UTC.

ich was stronger than normal. The blocking situation vaned during September 1995 [CPTEC/INPE, 1995b]. Daily vic analyses at the regional scale have shown that the ang situation persisted from August 1 to Scptember 15, After this date, cloudiness frequency and amount inad in the northern portion of the SCAR-B area. The end ic blocking event occurred due to the weakening of the idence induced by the SASH and to the easterly displace-

tof the midtropospheric anticyclone.

Wust of the SCAR-B region received little precipitation ic 2) in August and September, ranging from 0 to $100 \mathrm{~mm}$ the 2 month totals, which is not far from long-term mean is for the dry season. There was virtually no rainfall in - ust and in the first three weeks in September in the IR-B area. This dry situation started to change toward the of September when frontal systems caused the first rains of wason, putting an end to the dry conditions. Plate 3 shows mean temperature and mean temperature anomalies for zust and September 1995 with respect to the base period -1990 . In September, temperatures were up to $2.5^{\circ} \mathrm{C}$ mer than 30 year (1961-1990) average in the SCAR-B consistent with the negative rainfall anomalies. In agreeIt with the long-term mean features, the weather conditions -I the SCAR-B area were relatively stable during the SII nter, with reduced cloudiness and rainfall, increased haze, I low casterly winds. The pronounced dry season that oc red in all of the SCAR-B area can be accounted as partly ponsible for the large number of fires observed in central 17il, where total precipitation was less than $50 \mathrm{~mm}$ for those months.

Figure 2 shows the sea level pressure and $850 \mathrm{hPa}$ wind tors, averaged for the SCAR-B period (August 16 to Sepmer 20, 1995) for 1200 and 0000 UTC. Figure 3 is similar $\therefore$ for the $850 \mathrm{hPa}$ temperature based on CPTEC global NWP del analyses for the period. One can see the diurnal lower- of sea level pressure of $2-3 \mathrm{hPa}$ and temperature increase the SCAR-B area by comparing conditions at 0000 and 1200 IC. This is due to diurnal heating of the continent.

During most of the SCAR-B period, there were no signifiit precipitation events in central Brazil for two reasons: tly, absence of intense FS that could have brought episodic rainfall, and secondly, the large-scale subsidence associated to the westward influence of the SASH. This condition leads to high concentrations of smoke and haze over central Brazil and southern Amazonia. The aerosol loading can be so high as to strongly affect visibility, resulting in closing of airports throughout the regions, as happened, for example, on August 22, 1995, at the Rio Branco (AC) Airport.

\subsection{Significant Weather Events}

The surface wind intensification, in the morning of September 5, 1995, at Brasília Airport, causing cancelation of a programed ER-2 aircraft takeoff, was forecasted by the CTPEC global NWP model. Figure 4a shows a 24 hour forecast of winds valid on September 5, 1995, at 1200 UTC, when surface wind speeds arc in excess of $15 \mathrm{~m} \mathrm{~s}^{1}$ over the eastern SCAR-B area. The forecast was verified by the surface observations (Table 1) and by the MRF analysis of September 5, 1995, at 1200 UTC shown in Figure 4b. The wind intensification was due to interactions with an FS. This FS caused little rain, and moved rapidly offshore of Santa Catarina on September 2, reached Rio de Janciro on September 3, and Bahia on September 4, 1995 [CPTEC/INPE, 1995b]. The trailing high-pressure center $(1035 \mathrm{hPa})$, located at $35^{\circ} \mathrm{S} / 35^{\circ} \mathrm{W}$, was responsible for tightening the pressure gradient and thus the wind intensification farther inland on September 5, 1995.

The first FS that effectively organized convection and produced significant amounts of rainfall over central and southeastern Brazil occurred on Scptember 20, and it was forecasted by the meteorological staff. The GOES infrared satellite image for September 20, 1995 (Figure 5) shows the typical NW-SE oriented band of convective cloudiness over the western SCAR-B area, produced by penetration of a cold front sweeping through southeastern Brazil. Figure 6 shows the vertical structure of the atmosphere before (September 19, 1995, at 0000 UTC) and after the penetration of the frontal system (September 20, 1995, at 0000 UTC) in Campo Grande. It shows the typical sharp drop in lower troposphere temperatures and a strong inversion layer up to $700 \mathrm{hPa}$.

This cold front passage and associated rainfall determined an earlier end to the SCAR-B aircraft flights, partly due to the difficulty to detect smoke from the SCAR-B region on the 
(a) 24-h forecast

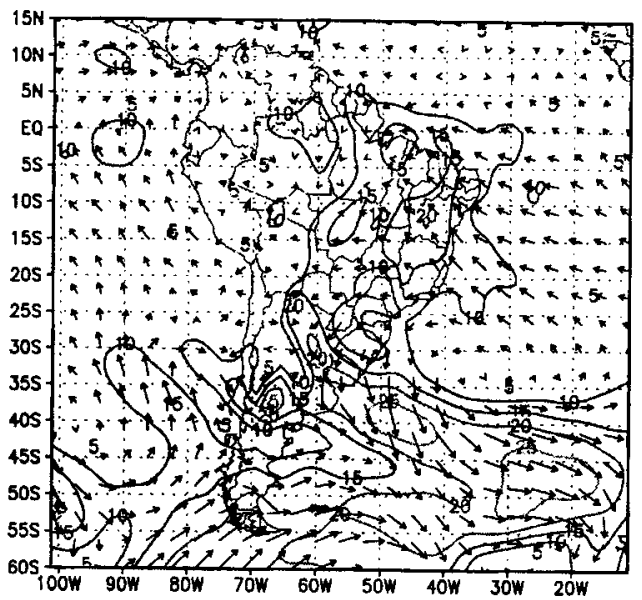

$\overrightarrow{20}$ (b) analysis

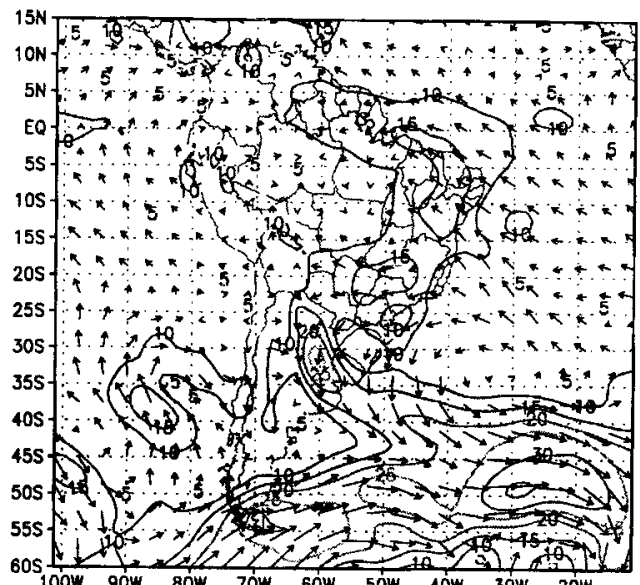

$\overrightarrow{20}$

Figure 4. The $850 \mathrm{hPa}$ horizontal wind field $\left(\mathrm{m} \mathrm{s}^{-1}\right)$ at $1200 \mathrm{UTC}$, September 5, 1995: (a) CPTEC 24 hour forecast and (b) MRF analysis.

programed flight trajectories between Brasilia and the Atlantic coast. Moreover, because of the dispersion of industrial pollutants from the Greater São Paulo area associated to the frontal passage, it was not recommended to continue the flights. A second major FS which organized convection swept through the region from September 28 to 30 and caused larger amounts of rainfall reaching up to $60 \mathrm{~mm}$ in 24 hours in Cuiabá. The two organized rainfall events (September 20-21 and 28-30) established the end of the dry season in most of the SCAR-B area. Only its northeastern sector remained dry until the end of September, which is consistent with the climatology of rainfall for that area where the rainy season starts in October-November.

\section{Trajectories of Air Particles in SCAR-B Areas}

To estimate the spreading of gas and aerosol emissions from areas with intense biomass burning, numerical simulation of the forward and backward trajectories of air particles has been applied. The calculations were carried out using the CPTEC database which includes analyses and five days forecasts for horizontal wind, vertical velocity $\omega$, temperature, and geopotential on the grid with $1.874^{\circ} \times 1.875^{\circ}$ horizontal resolution.

For calculation of the trajectories of air particles, Crank-

Table 1. Surface Winds at Brasilia Airport Station (Latitude $15.87^{\circ} \mathrm{S}$, longitude $47.93^{\circ} \mathrm{W}$ ), September 5,1995

\begin{tabular}{ccc}
$\begin{array}{c}\text { Time, } \\
\text { UTC }\end{array}$ & Direction & $\begin{array}{c}\text { Speed, } \\
\mathrm{m} \mathrm{s}^{-1}\end{array}$ \\
\hline 10 & SE & 7.0 \\
11 & NE & 14.0 \\
12 & E & 17.0 \\
13 & SE & 20.0 \\
14 & SE & 20.0 \\
15 & E & 20.0 \\
16 & NE & 20.0 \\
17 & E & 9.0 \\
18 & NE & 3.0 \\
\hline
\end{tabular}

Nicolson time integration scheme was used [Williamson and Rasch, 1989]:

$$
\mathbf{X}_{t i}-\mathbf{X}_{t l}=\frac{\Delta t}{2}\left(\mathbf{V}_{t i}+\mathbf{V}_{t}\right)
$$

where the index $a$ refers to arrival point, and the index $d$ refers to departure point, $\mathbf{X}$ and $\mathbf{V}$ are the vectors of a particle location and a wind velocity, respectively. They are three-

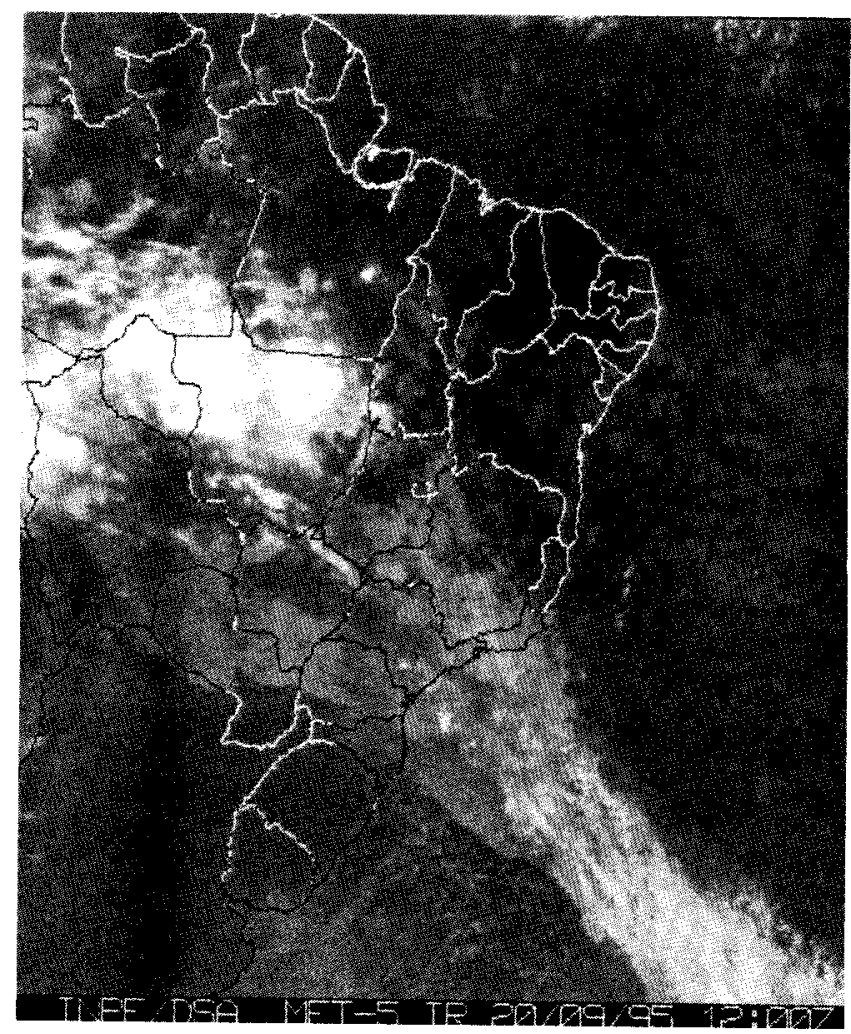

Figure 5. Meteosat-5 IR image for 1200 UTC, September 20,1995 . 
(a)

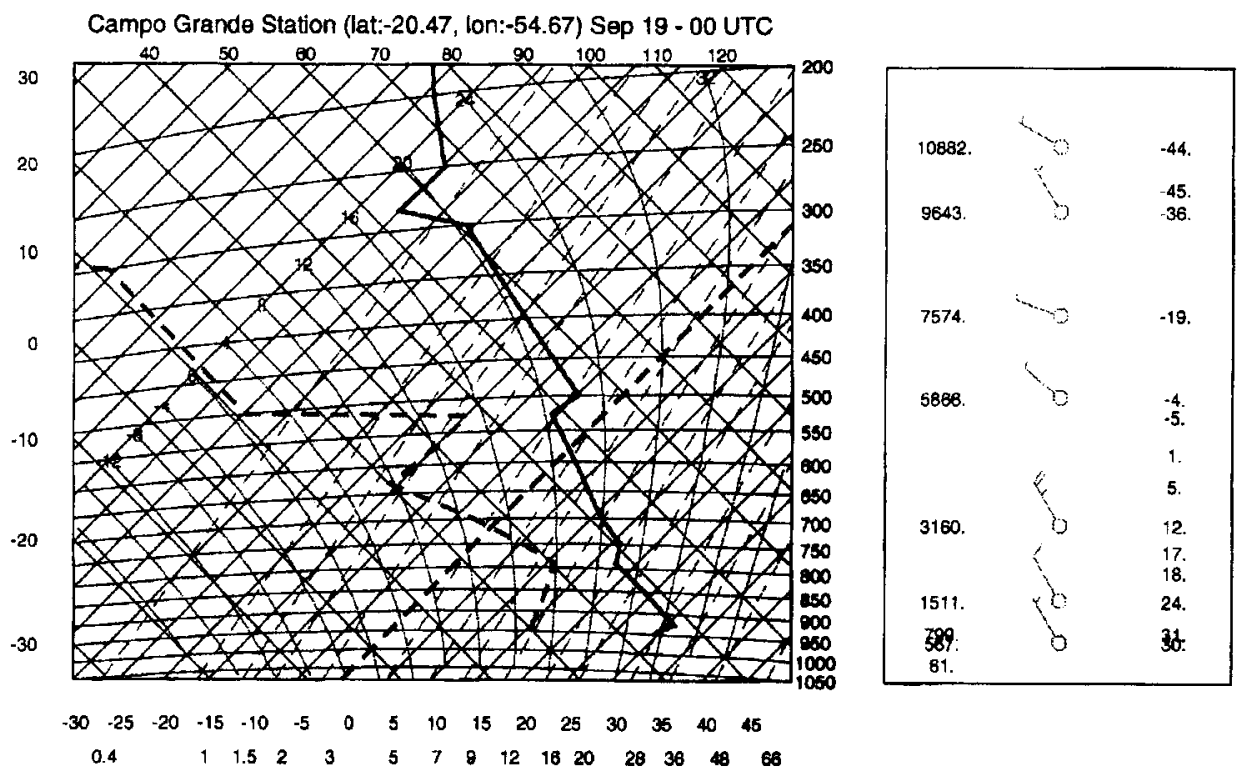

(b)

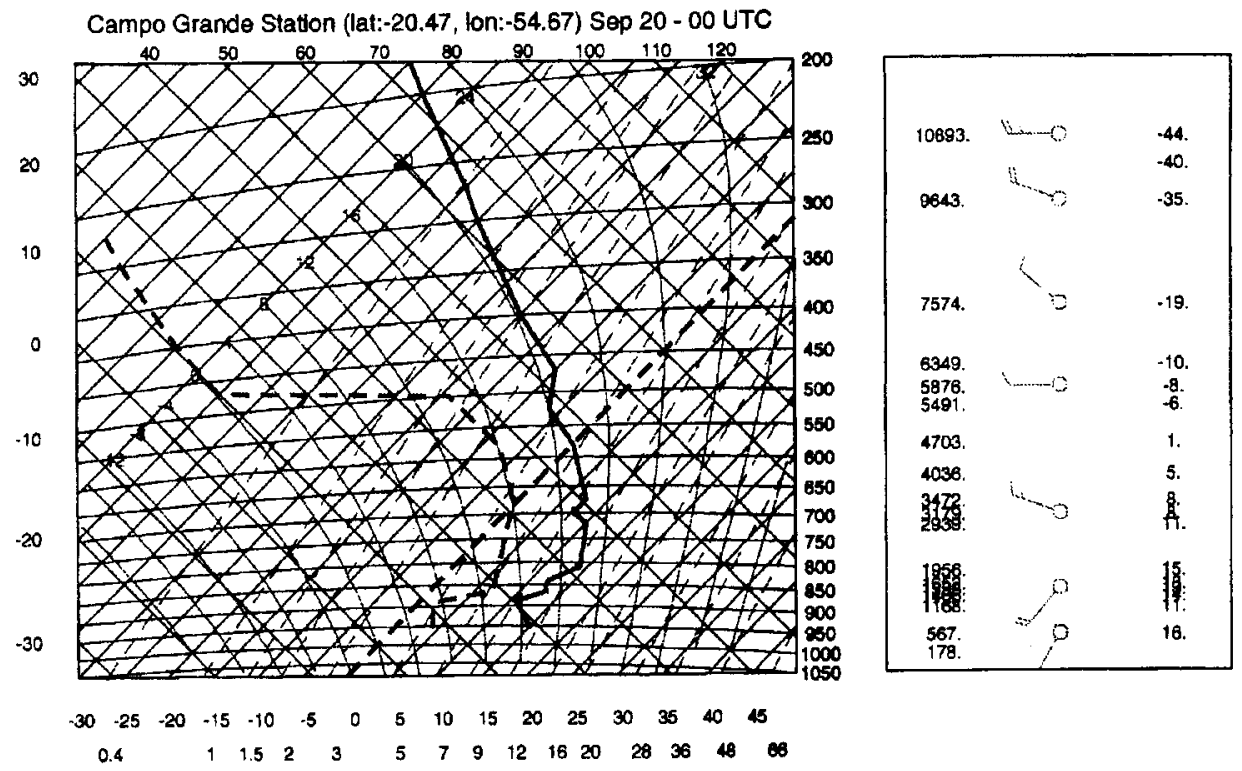

Figure 6. Campo Grande (MS) tephigram for September 1995, 0000 UTC: (a) 19 and (b) 20.

mensional vectors for the kinematic trajectory model and o-dimensional vectors for motion of air particles on isen-opic surfaces.

This implicit equation may be integrated forward or backard by iterations. The unknown wind components for air - sticles are obtained by quasi-monotone local spline interpostion [Bermejo and Staniforth, 1992]. Calculation of the loca:on of the air particle, its height relative to sea level, and to the upography are made with time step $\Delta t=1$ hour. Plate 4 hows an example of the backward trajectory calculations for the period from August 23 to 28, 1995. By the end of this reriod the air masses within $35^{\circ} \mathrm{S}$ to $25^{\circ} \mathrm{S}$ and $60^{\circ} \mathrm{W}$ to $55^{\circ} \mathrm{W}$ consist of three types of air particles. The first type is the air articles which have come from Pacific Ocean and are located above $2 \mathrm{~km}$. They moved on the isentropic surface $315^{\circ} \mathrm{K}$. The second type of air mass is located between 1 and $2 \mathrm{~km}$ and comes from Amazonia (isentropic surface $308^{\circ} \mathrm{K}$ ). This type of air mass has brought smoke from Amazonia region. The particles below $1 \mathrm{~km}$ with potential temperature $305^{\circ} \mathrm{K}$ come from the São Paulo region.

In Plate 5 one can see an example of forward trajectories in Amazonia. These forward trajectories have been calculated using the three-dimensional wind field. Their starting points represent typical biomass burning areas during SCAR-B. For a detailed description of sources, see Trosnikov and Nobre [this issue]. They began on the levels with the heights 500,1000 , and $1500 \mathrm{~m}$ in the four geographical points with the coordinates: $54^{\circ} \mathrm{W}, 9.5^{\circ} \mathrm{S} ; 52^{\circ} \mathrm{W}, 18.5^{\circ} \mathrm{S} ; 55^{\circ} \mathrm{W}, 17^{\circ} \mathrm{S}$; and $48.5^{\circ} \mathrm{W}, 13.5^{\circ} \mathrm{S}$. Plates $5 \mathrm{a}$ and $5 \mathrm{~b}$ show that the air particles, which started August 20 and 21, 1995, moved generally to the northwest. 
After August 23 the flow had becn split, and two systems of the trajectories have been observed (see Plates $5 \mathrm{c}$ and $5 \mathrm{~d}$ ). This radical change of bchavior of air currents was connected with the intensification of the high-pressure center in the tropical Southern Atlantic.

\section{Change of Solar Radiation Budget of Atmosphere-Surface System by Smoke Hazes Observed During SCAR-B}

Smoke aerosol particles absorb and scatter solar radiation, changing the radiation balance at the top of the atmosphere and at the Earth's surface. In recent studies there are apparent uncertaintics concerning the cvaluation of the tropospheric aerosol impact on a solar irradiance and climatic variables. The aerosols with different optical parametcrs can cause either an increase or decrease of the solar radiation absorption in the atmosphere-surface system and, as a result, a heating or cooling at the surface, respectively. Tropospheric aerosols lead to the opposite radiation effects in the atmosphere and at the surface, which have to be studied also. To evaluate the radiation effects of smoke aerosols of large biomass burning in Amazonia, we carried out the calculations using the broadband radiation code with the column aerosol optical thickness and precipitable water derived from the Sun photometer measurements taken during SCAR-B. The developed radiation code and the parameters of the atmosphere adopted for use in the computations are described in detail by Tarasova et al. [this issue]. We calculated the solar radiation absorption in the atmosphere and at the surface separately. Three periods of the Sun photometer measurements, made under the clear sky conditions at Cuiabá and Potosi Mine sites at a 15 min sampling interval, were considered. They were characterized by the low, medium, and heavy aerosol loading of the atmosphere. Table 2 presents aerosol optical thickness and the precipitable water, averaged over each period. Smoke was located in the lower 4 $\mathrm{km}$ layer. The radiation computations below $12 \mathrm{~km}$ were performed using the continental acrosol optical model with the single-scattering albedo at the wavelength $550 \mathrm{~nm}$ equal to $\omega_{0}^{550}=0.89$. Smoke was located in the lower $4 \mathrm{~km}$ layer. The calculations were made also with the aerosol single-scattering albedo in the visible region of solar spectrum obtained from the comparison of the measured and computed solar irradiance at the surface (T. A. Tarasova et al., unpublished data, 1997). For cases 1 and 2 there was obtained the value $\omega_{0}^{550}=$ 0.86 in the lower $4 \mathrm{~km}$ layer, and $\omega_{0}^{5.50}=0.95$ for case III.

The difference of the solar radiation absorption computed with the aerosol loading of the atmosphere and without it, or aerosol radiative forcing, is shown in Figure 7 as function of the cosine of the solar zenith angle. It is seen that the smoke aerosol particles decrease the solar absorption at the surface at the value from -40 to $-300 \mathrm{~W} / \mathrm{m}^{2}$, depending on the aerosol optical thickness and the solar zenith angle. There is almost the same increasing of the absorption in the atmosphere column, taking place in the lower $4 \mathrm{~km}$ layer, where smoke is usually located. The aerosol radiative forcing at the top of the atmosphere is from -5 to $-50 \mathrm{~W} / \mathrm{m}^{2}$. It strongly depends on the solar zenith angle and increases in 2 times when the angle changes from $25^{\circ}$ up to $65^{\circ}$. The sensitivity of the calculation results to the aerosol single-scattering albedo, varied from $\omega_{0}^{550}$ $=0.89$ to $\omega_{0}^{550}=0.86$, is not large for cases 1 and 2 of the low and middle smoke aerosol turbidity. The change of the aerosol single-scattering albedo from $\omega_{0}^{550}=0.89$ to $\omega_{0}^{550}=0.95$ for the heavy smoke haze, case 3 , results in the large differences of the value of the computed aerosol radiative forcing.

The described results were obtained using the approximate broadband radiation code and the specific acrosol optical model. It can be considered as the illustrative test cases for the more sophisticated radiation calculations, taking into account the detailed knowledge of the smoke aerosol optical parameters, particularly in the near-infrared region of the solar spectrum.

\section{Conclusions}

Accurate short- and medium-range weather forecasts are fundamental for field experiments involving aircraft. They became cven more crucial when there are special aircrafts in the mission, such as the high-altitude flying ER-2. This aircraft needs a long landing runway, available only in Brasília for the SCAR-B area. An inaccurate short-range forccast could put to risk the mission since there would be no airports in southern Amazonia for the aircraft to land. Mainly for that reason, a meteorological office was established in Brasília to support the mission flights and ficld activities. The weather forecasts were based on numerical weather products from CPTEC and from NCEP, operational satellites imagery, and observations from surface and upper air stations. Although the dry season in central Brazil is rather eventless in terms of extreme weather events, the forecasting capability proved to be useful. For instance, it correctly forecasted the strong winds on September 5 , 1995, which forced the ER-2 to ground. It also accurately predicted the rain-producing frontal system on September 20, 1995, which brought the SCAR-B field experiment to an end.

The atmospheric conditions throughout the SCAR-B period of August and September 1995 were near long-term mean conditions, typical dry season in central Brazil and southern Amazonia. Precipitation ranging between 0 and $50 \mathrm{~mm}$ was slightly below normal, primarily in September. The mean temperatures, consistent with the small precipitation anomalies, were slightly higher than average up to $2.5^{\circ} \mathrm{C}$. The winds werc light to moderate easterlies over most of the region. Stable conditions prevailing throughout the region, associated to large-scale subsidence, inhibited dispersion of smoke from biomass burning for most of the SCAR-B period. Long periods of haze, low humidity, and also little cloudiness and rain occurred during the mission partly due to blocking of frontal systems in the southeastern Pacific. The stable situation was interrupted by the penctration of a frontal system on September 20-21, 1995 , and a second and more rain-producing one on September $28-30,1995$. Those two frontal systems in a period of 10 days brought an end to the dry scason.

Trajectory calculations for the period showed that most of the smoke below $4 \mathrm{~km}$ was transported to the south and then

Table 2. Threc Periods of Sun Photometer Measurements During SCAR-B Under Clear Sky Conditions With Smoke Haze

\begin{tabular}{cccccc}
\hline Period & \multicolumn{1}{c}{ Site } & 1995 & $\begin{array}{c}\text { Local Standard } \\
\text { Time }\end{array}$ & $\bar{\tau}_{550}$ & $P_{1}$ \\
\hline 1 & Cuiabá & Aug. 28 & $0730-1145$ & 0.344 & 1.89 \\
2 & Cuiabá & Aug. 27 & $1145-1600$ & 0.744 & 1.41 \\
3 & Potosi Mine & Sept. 5 & $0900-1045$ & 2.14 & 4.13 \\
\hline
\end{tabular}

The value $\tau_{550}$ is the column aerosol optical thickness at $550 \mathrm{~nm} ; P_{\text {n }}$ is the precipitable water in centimeters. 

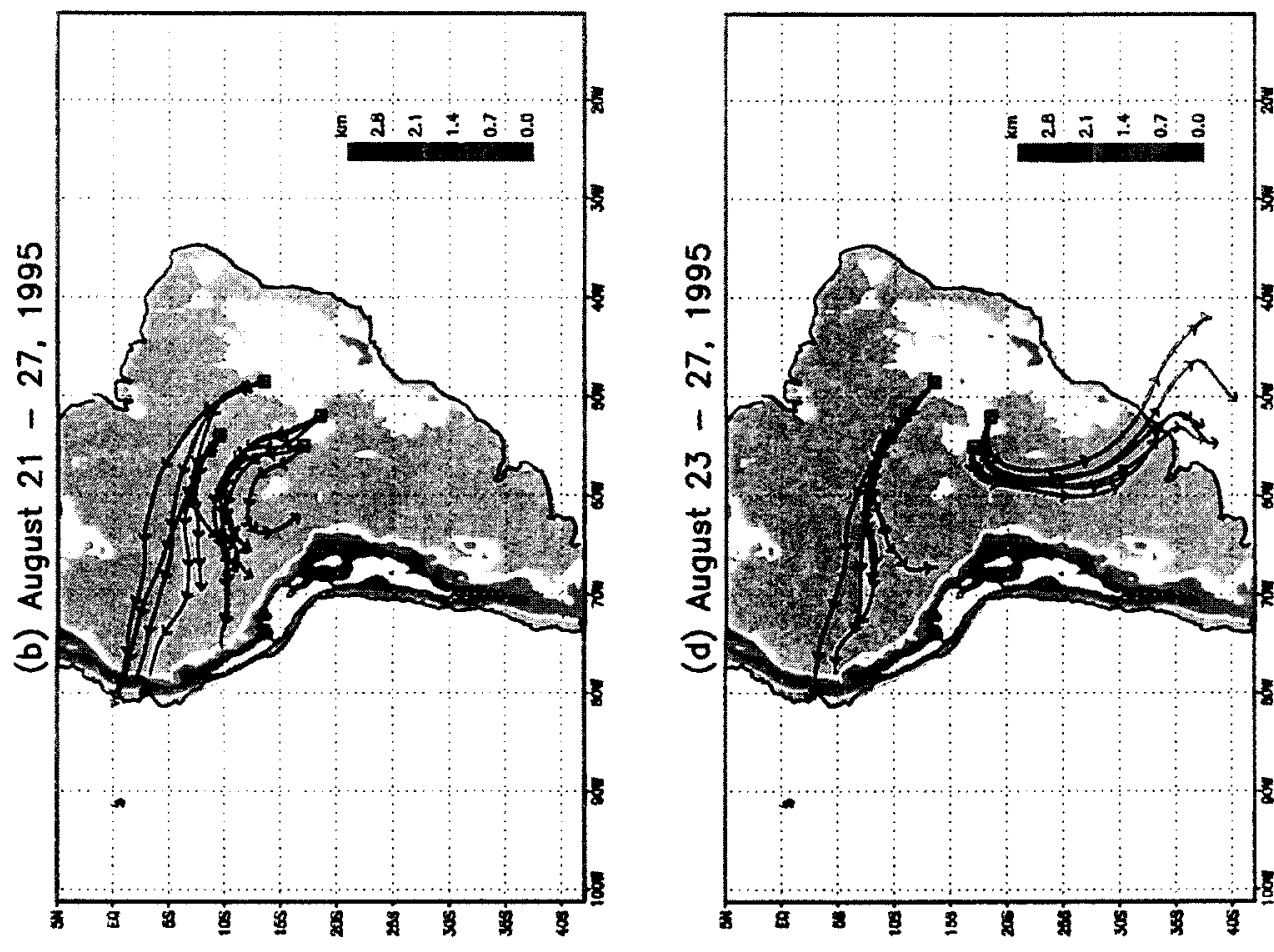

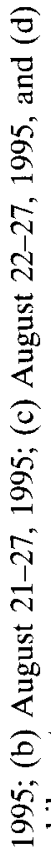
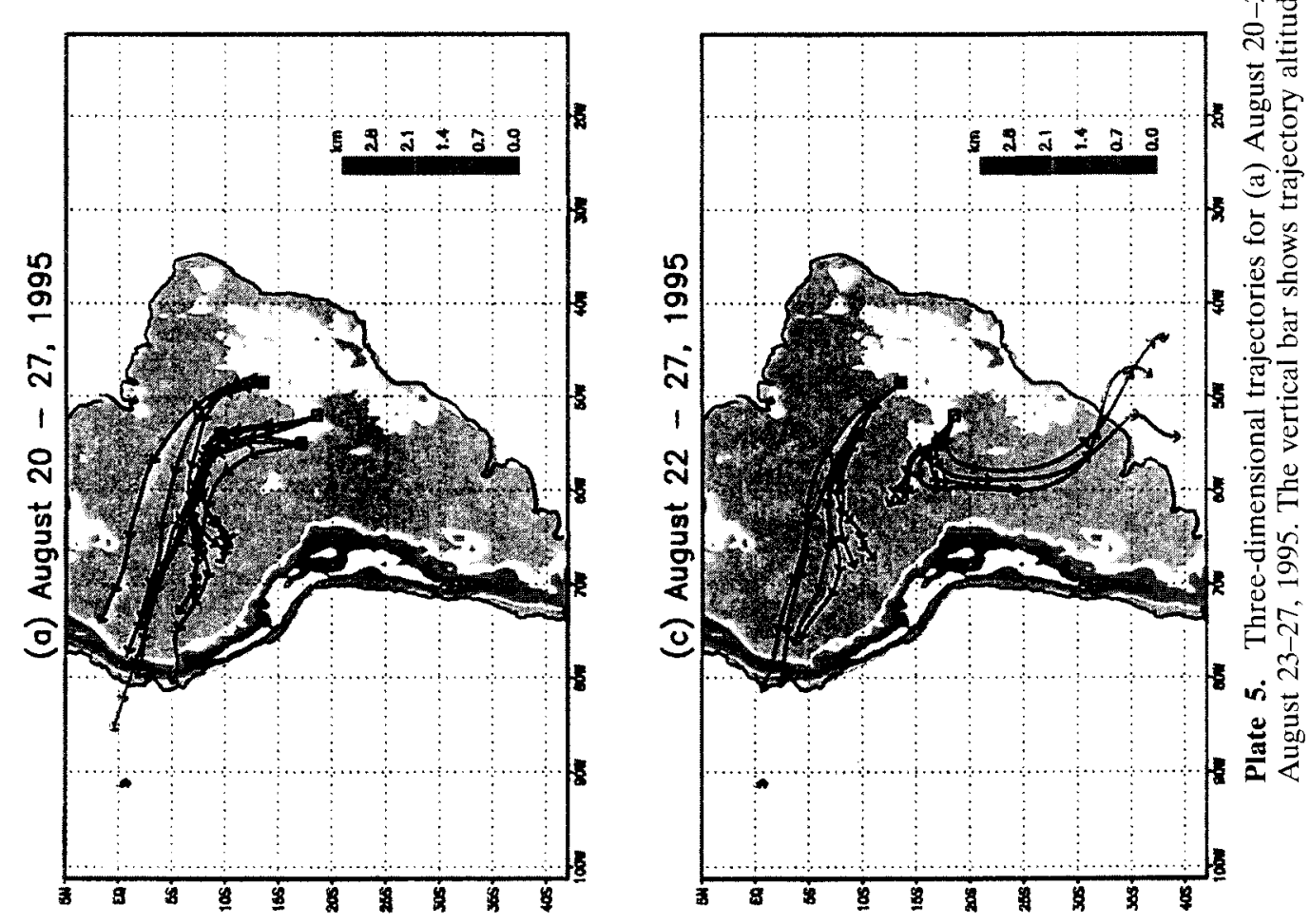

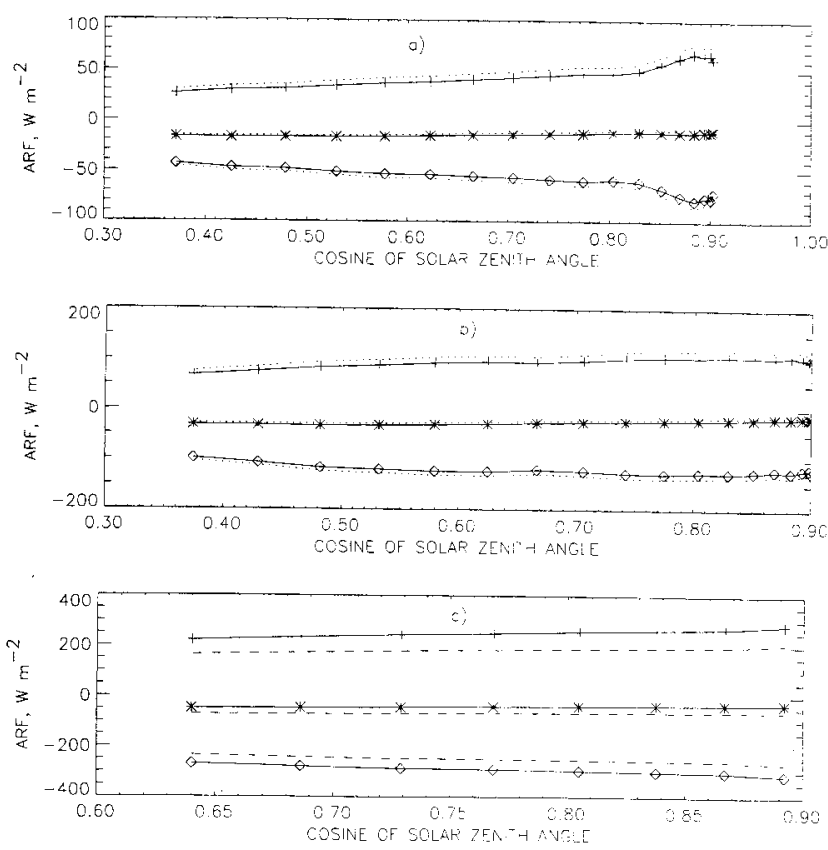

Figure 7. Change of the solar radiation absorption due to aerosols, or aerosol radiative forcing (ARF), in the atmosphere-surface system denoted by asterisk, at the surface given by diamonds, and in the atmosphere column denoted by pluses. It was computed with the aerosol optical depth and precipitable water measured during (a) period 1 , (b) period 2 , (c) period 3 of SCAR-B measurements shown in Table 2 . Dotted and dashed curves present the calculation results obtained with $\omega_{0}^{550}=0.86$ and $\omega_{0}^{550}=0.95$, respectively.

to the east at $25^{\circ} \mathrm{S}$ to $30^{\circ} \mathrm{S}$ exiting the continent into the Atlantic Ocean. A calculation of the changes of radiation balance due aerosol loading using a radiative transfer model indicated that the aerosol radiative forcing can be substantial for observed cases of heavy aerosol loadings. All the meteorological data collected during the SCAR-B have been archived and are available to the scientific community.

Acknowledgments. Two coauthors (Tarasova and Trosnikov) are supported by a RHAE/CNPQ grant for visiting scientists. We would like to express our special gratitude to Instituto Nacional de Meteorologia (INMET), Centro Técnico Aeroespacial (CTA), and Destacamento de Proteção ao Vôo (DPV). We also thank Letícia M. B. de Faria for helping to prepare the figures.

\section{References}

Alessandro, A. P., and E. R. Liechtenstein, Anomalias persistentes de la circulacion atmosferica durante la scquia del inverno de 1995 , paper presented at Anales del VII Congreso Latinoamericano de Meteorologia, Cent. Argent. de Meteorol., Buenos Aires, 1996.

Berbery, E. H., and C. S. Vera, Characteristics of the Southern Hemisphere winter track with filtered and unfiltered data, J. Atmos. Sci., 53, 468-481, 1996.

Bermejo, R., A. Staniforth, The conversion of semi-Lagrangian advection schemes to quasi-monotone schemes, Mon. Weather Rev., 120, 2622-2632, 1992.

CPTEC/INPE, Climanálise-Boletim de Monitoramento e Análise Climática, Inst. Nacl. de Pesqui. Espaciais, São José dos Campos, Brazil, 1995a.

CPTEC/INPE, Climanálise-Boletim de Monitoramento e Análise Climática, Inst. Nacl. de Pesqui. Espaciais, São José dos Campos, 1995b. CPTEC/INPE, Climanálise-Boletim de Monitoramento e Análise
Climática, Edição Comemorativa de 10 anos, Inst. Nacl. de Pesqui. Espaciais, São José dos Campos, 1996.

D'Almeida, C., and A. M. Grimm, Condiçōes globais durante fases secas e úmidas de estação chuvosa no Estado de São Paulo, paper presented at Anais do IX Congresso Brasileiro de Meteorologia, Sos. Brasil. de Meteorol., Campos do Jordāo, Novembro, 1996.

Figueroa, S. N., Estudo dos Sistemas de Circulação de verāo sobre a América do Sul e sua simulação com modelos numéricos, Ph. D. thesis, Inst. Nacl. de Pesqui. Espaciais, São José dos Campos, São Paulo, 1997.

Figueroa, S. N., and C. A. Nobre, Precipitation distribution over central and western tropical South America, Climanálise, 5(06), 36-45, 1990.

Figueroa, S. N., P. Satyamurty, and P. L. Silva Dias, Simulations of the summer circulation over the South American region with an Eta circulation model, J. Atmos. Sci., 52, 1573-1584, 1995.

Gan, M. A., and V. B. Rao, The influence of the Andes Cordillera on transient disturbances, Mon. Weather Rev., 122, 1141-1157, 1994.

Garrido, A. C., J. A. Marengo, C. Iracema, and A. da Silva, Cold outbreaks over tropical and extratropical South America during 1985-1993, J. Clim., in press, 1997.

Horel, J. A., N. Hahmann, and J. Geisler, An investigation of the annual cycle of convective activity over the tropical Americas, J. Clim., 2, 1388-1403, 1989.

Kaufman, Y. J., et al., Smoke, Clouds, and Radiation-Brazil (SCAR-B) experiment, J. Geophys. Res., this issue.

Kodama, Y., Large-scale common features of subtropical precipitation zones (The Baiu frontal zone, the SPCZ and the SACZ), I, Characteristics of subtropical frontal zones, J. Meteorol. Soc. Jpn., 70, 813-836, 1992.

Kousky, V. E., Frontal influences on northeast Brazil, Mon. Weather Rev., 107, 1140-1153, 1979.

Kousky, V. E., Pentad outgoing longwave radiation climatology for South American sector, Rel: Bras. Meteorol., 3(1), 217-231, 1988.

Kousky, V. E., and M. T. Kagano, A climatological study of the tropospheric circulation over the Amazon region, Acta Amazonica, II(4), 743-758, 1981.

Kousky, V. E., and L. C. Molion, Uma contribuição à climatologia da dinâmica da troposfera sobre a Amazônia, São José dos Campos, INPE-2030-RPE/0503, Inst. Nacl. de Pesq., 1981.

Marengo, J., C. Nobre, and A. Culf, Climatic impacts of the friagens in forested and deforested regions in Amazon Basin, J. Appl. Meteorol, 36(11), 1553-1566, 1997.

Nascimento, E., and T. Ambrizzi, Aspectos dinâmicos-sinóticos associados à ocorrência de bloqueios próximos à América do Sul no inverno de 1995, paper presented at Anais do IX Congresso Brasileiro de Meteorologia, Soc. Brasil. de Meteorol., Campos do Jordão, Novembro, 1996.

Nún̄ez S. E., E. E. Gentile, and J. H. Hordij, Anomalías de la precipitación en la región húmeda Argentina durante 1995 y sus impactos en las actividades productivas, paper presented at Anales del VII Congreso Latinoamericano de Meteorologia, Bs. As., 2-6 Septiember, 1996.

Oliveira, A. S., and C. A. Nobre, Interaçōes entre sistemas frontais na América do Sul e a convecção na Amazônia, Anais do IV Congresso Brasileiro de Meteorologia, Belo Horizonte, 1, 315-316, 1986.

Parmenter, F., A southern hemisphere cold front passage at the equator, Bull. Am. Meteorol. Soc., 57, 1435-1440, 1976.

Rao, V. B., I. F. A. Cavalcanti, and K. Hada, Annual variation of rainfall over Brazil and water vapor characteristics over South America, J. Geophys. Res., 101, 26,539-26,551, 1996.

Sugahara, S., Flutuaçōes interanuais, sazonais e intrasazonais no Estado de São Paulo, Ph.D. thesis, Inst. Astron. e Geofís., Univ. de São Paulo, São Paulo, Brazil, 1991.

Trosnikov, I. V., and C. A. Nobre, Estimation of acrosol transport from biomass burning areas during the SCAR-B experiment, $J$. Geophys. Res., this issue.

Williamson, D., and P. Rasch, Two dimensional semi-Lagrangian transport with shape-preserving interpolation. Mon. Weather Rev., $117,102-109,1989$.

C. P. Dereczynski, L. F. Mattos, C. A. Nobre, T. A. Tarasova, and I. V. Trosnikov, Centro de Previsão de Tempo e Estudos Climáticos/ Instituto Nacional de Pesquisas Espaciais, Rodovia Presidente Dutra, km 39, Cachoeira Paulista, São Paulo, Brazil 12630-000. (e-mail: nobre(acptec.inpe.br)

(Received September 9, 1997; revised March 5, 1998; accepted March 6, 1998.) 